\title{
THE “PORŢILE DE FIER/IRON GATES” NATURE PARK (ROMANIA) SOME DANUBE NORTHERN TRIBUTARIES FISH FAUNA
}

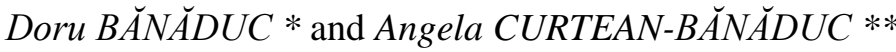

* "Lucian Blaga” University of Sibiu, Faculty of Sciences, Applied Ecology Research Center, Dr. Ioan Raţiu Street 5-7, Sibiu, Sibiu County, Romania, RO-550012, ad.banaduc@yahoo.com

** "Lucian Blaga” University of Sibiu, Faculty of Sciences, Department of Ecology and Environment Protection, Dr. Ioan Raţiu Street 5-7, Sibiu, Sibiu County, Romania, RO-550012, angela.banaduc@ulbsibiu.ro

DOI: 10.1515/trser-2015-0040

KEYWORDS: Berzasca, Sirinia, Liubcova and Mraconia rivers, fish fauna.

\section{ABSTRACT}

The relative larger size of the Berzasca River, respectively the relatively constant environmental conditions, with relatively stenotopic ichthyocenosis, suffered small qualitative and quantitative fish fauna modifications in time, compared to the smaller rivers such as Sirinia, Liubcova/Oreviţa and Mraconia. The Danube "Iron Gates” I Lake influences the lower sectors of the studied rivers in term of fish species exchange. The accidental droughts in the karstic zones of the studied lotic sectors have a negative influence on the spatial continuity of the local fish fauna, and the climate change can increase these influence in the future. All the studied rivers play an important role for the near Danube "Iron Gates" I Lake lotic fish species of small-medium size, as reproduction and shelter habitats.

RESUMEN: Ictiofauna de algunos tributarios del norte del Danubio en el Parque Natural "Puertas de Hierro" (Rumania).

El tamaño del Río Berzasca, que es relativamente grande, sus condiciones ambientales, que son mas o menos constantes y su ictiofauna, que es básicamente estenotípica, sufrieron cambios cualitativos y cuantitativos en el tiempo, en comparación con ríos más pequeños como el Sirinia, Liubcova/Oreviţa y el Mraconia. En términos de intercambio de la ictiofauna, el Parque Natural Las "Puertas de Hierro" I, en el Lago Danubio, tiene una gran influencia en los sectores bajos de los ríos aquí estudiados. Las sequías accidentales en la parte cárstica de estos sectores lóticos tienen una influencia negativa sobre la continuidad íctica local y los cambios climáticos pudieran incrementar esa influencia en el futuro. Todos los ríos estudiados juegan un papel importante como hábitat reproductivo y de refudio para los peces medianos del Danubio en el Parque Nacional "Puertas de Hierro".

REZUMAT: Ihtiofauna unora dintre tributarii nordici ai Dunării din Parcul Natural "Porțile de Fier" (România).

Datorită dimensiunii relativ mari a râului Berzasca, respectiv condiţiilor relativ constante de mediu, ihtiocenozele relativ stenotopice ale acestui râu, au suferit modificări calitative şi cantitative reduse în timp, în comparaţie cu râurile mai mici cum ar fi Sirinia, Liubcova/Oreviţa şi Mraconia. Lacul Porțile de Fier I influenţează sectoarele inferioare ale râurilor studiate din punctul de vedere al schimburilor de specii. Secetele accidentale din zonele carstice ale sectoarelor lotice studiate au influenţe negative asupra continuităţii spaţiale ale faunei ihtiologice locale, şi schimbările climatice pot creşte aceste influenţe în viitor. Toate râurile studiate joacă un rol important pentru speciile de peşti de dimensiuni mici-medii din lacul Porţile de Fier I din proximitate, ca habitate de reproducere şi adăpost. 


\section{INTRODUCTION}

In the last century the Lower Danube River, Danube Delta and North-West Black Sea area experienced significant decreases in habitat heterogeneity and quality, fish diversity and stock abundance (Antipa 1909, 1941; Bănărescu, 1964; Bănăduc et al., 2014). The "Iron Gates” Danube area is in the same situation (Bănăduc et al., 2014). The complex topography and history of this area, combining a natural gorge relief and extensive anthropogenic impacts ranging from pollution, hydrotechnical works, fish overexploitation and poaching, create obstacles for the lotic fish species of the Danube tributaries in this area, leading to changes in population and diversity. This paper identify some of the modifications to ichthyocenoses structure in some of the northern Danube tributaries, updating the knowledge of this area since the previous work around fifty years ago (Bănărescu, 1964; Bușniță et al., 1970).

This study focuses on four Danube tributaries, the Berzasca, Sirinia, Liubcova/Oreviţa and Mraconia, considering their input of water from the West Carpathian range. Relatively high flows and floods are not unusual in winter and spring, with over $50 \%$ of the flows coming from rain and snow. Some karst also contribute to subterranean water sources. Based on water flow quantities, the Berzasca River can be considered as a big mountain river, and Sirinia, Liubcova/Oreviţa and Mraconia are small mountain rivers. (Ujvari, 1972) The predominantly mountainous relief of the river basin areas induces high speed sediments flow, the majority being coarse dragged material (e.g. gravel and boulders) and a minority of sediments being in suspension. These tributary sectors of the Danube River are no longer influenced by the natural hydrological regime (variations in flow and groundwater levels) of the Danube, a relationship that existed even before the formation of the "Iron Gates" Lake I (Ujvari, 1959). Qualitatively speaking these lotic systems are negatively influenced only in the lower course sectors, where organic pollution is present and also some semi-lenitic eutrophic sectors appear, formed in the proximity of the confluences with the "Iron Gates" I Lake at relatively high water.

In the lower segments of these tributaries in the above mentioned confluence areas there is a man-made trend of increased water levels with large oscillations, turbidity and reduced water current speeds, an increase of sedimentation, increase of phytoplankton mass and a decrease of the litho-rheophile benthic fauna - all a consequence of the impact of the higher water level in the "Iron Gates" I Lake. In general, more or less significant differences can be observed between the structures of the benthic macroinvertebrate communities upstream and downstream of the confluence with the Danube, a result of the different features of the lentic habitat downstream and upstream, the latter having predominantly mountain river characteristics (Curtean-Bănăduc, 2014). Generally, in these confluence areas, the transition from litho-rheophile, psamo-rheophile, and psamo-pelo-rheophile habitat sections to psamosemistagnophile, and psamo-pelo-semistagnophile habitat sectors is noticeable.

The variety of the landscape, the specificity of the climate, the proximity of the Danube and least, but not last, the human impact in the region raise the question of whether the studied tributaries represent a sheltered enclave for the specific fish fauna in the medium term, or whether they represent lotic sub-systems indirectly influenced by the Danube River.

This research aims to analyse the potential changes due to natural and anthropogenic factors on the fish communities of certain Danube River tributaries of the „Iron Gates” area (Fig. 1): Berzasca, Sirinia, Liubcova/Oreviţa and Mraconia. The available ichthyofauna elements in the studied four Danube tributaries were evaluated through comparison of the half century old data (Bănărescu, 1964) and the present paper author's field data. 


\section{MATERIAL AND METHODS}

Fish samples for this study were collected in 2010-2012, in Berzasca, Sirinia, Liubcova, and Mraconia rivers (Fig. 1). The fish was identified and immediately released in situ: Salmo trutta fario, Thymallus thymallus, Esox lucius, Squalius cephalus, Phoxinus phoxinus, Tinca tinca, Scardinius erithrophthalmus, Aspius aspius, Alburnus alburnus, Alburnoides bipunctatus, Blicca bjoerkna, Abramis brama, Vimba vimba, Chondrostoma nasus, Rhodeus sericeus amarus, Gobio gobio obtusirostris, Gobio alpininnatus, Barbus barbus, Barbus meridionalis, Cyprinus carpio, Carasius gibelio, Orthrias barbatulus, Misgurnus fosilis, Cobitis taenia, Sabanejewia aurata balcanica, Sabanejewia aurata bulgarica, Silurus glanis, Lota lota, Lepomis gibosus, Perca fluviatilis, Acerina cernua, Gobius fluviatilis, Gobius kessleri and Cottus gobio.

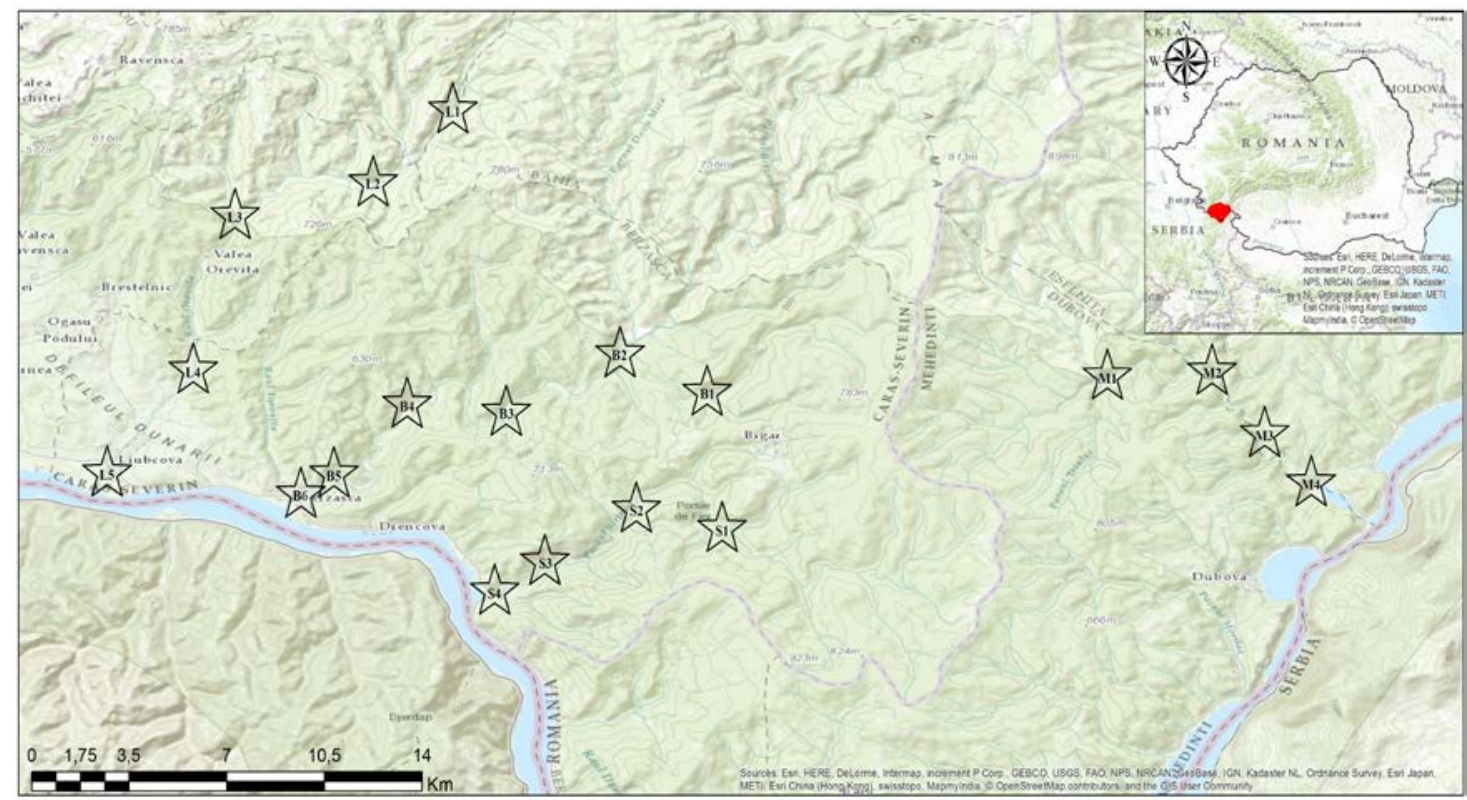

Figure 1: The location of sampling stations on the studied rivers:

Berzasca (B1 - B6), Sirinia (S1 - S4), Liubcova/Oreviţa (L1 - L5), and Mraconia (M1 - M4).

\section{RESULTS AND DISCUSSION}

\section{Berzasca River}

Berzasca is a perennial river that never runs dry even in the hottest summer. It falls into the river category characterised by an area of watershed between 200 and $1,500 \mathrm{~km}^{2}$, length of the river between 30 and $100 \mathrm{~km}$ and mean discharge between 0.5 and $15 \mathrm{~m}^{3} / \mathrm{s}$ (Tetelea, 2014).

The ichthyofauna of the Berzasca River is characterized by the presence of Salmo trutta fario (Fig. 2) in the studied area, an unexpected species that was possibly introduced to the river by humans (Paşovschi, 1956). Fish species that would be expected, but which are missing from the characteristic ichthyologic trout zone include: Cottus gobio and Phoxinus phoxinus. The brown trout dominates in the upstream section until around $30 \mathrm{~km}$ sector and it is considered an indicator of a steady situation in the river over the last half of century in this 
section. In the Merridionnal barbel and Grayling zone. Barbus meridionalis is one of the most successful and abundant fish species of this river, although Thymallus thymallus continues to be absent, as was observed in the earlier work on the river. Orthrias barbatulus and Alburnoides bipunctatus appear to have a good and stable population in this river, reflecting the earlier study's finding. The populations of Chondrostoma nasus and Vimba vimba in the Danube still have positive influences in the lower sector of Berzasca River, especially during the reproduction season. Squalius cephalus also has an abundant stable population.

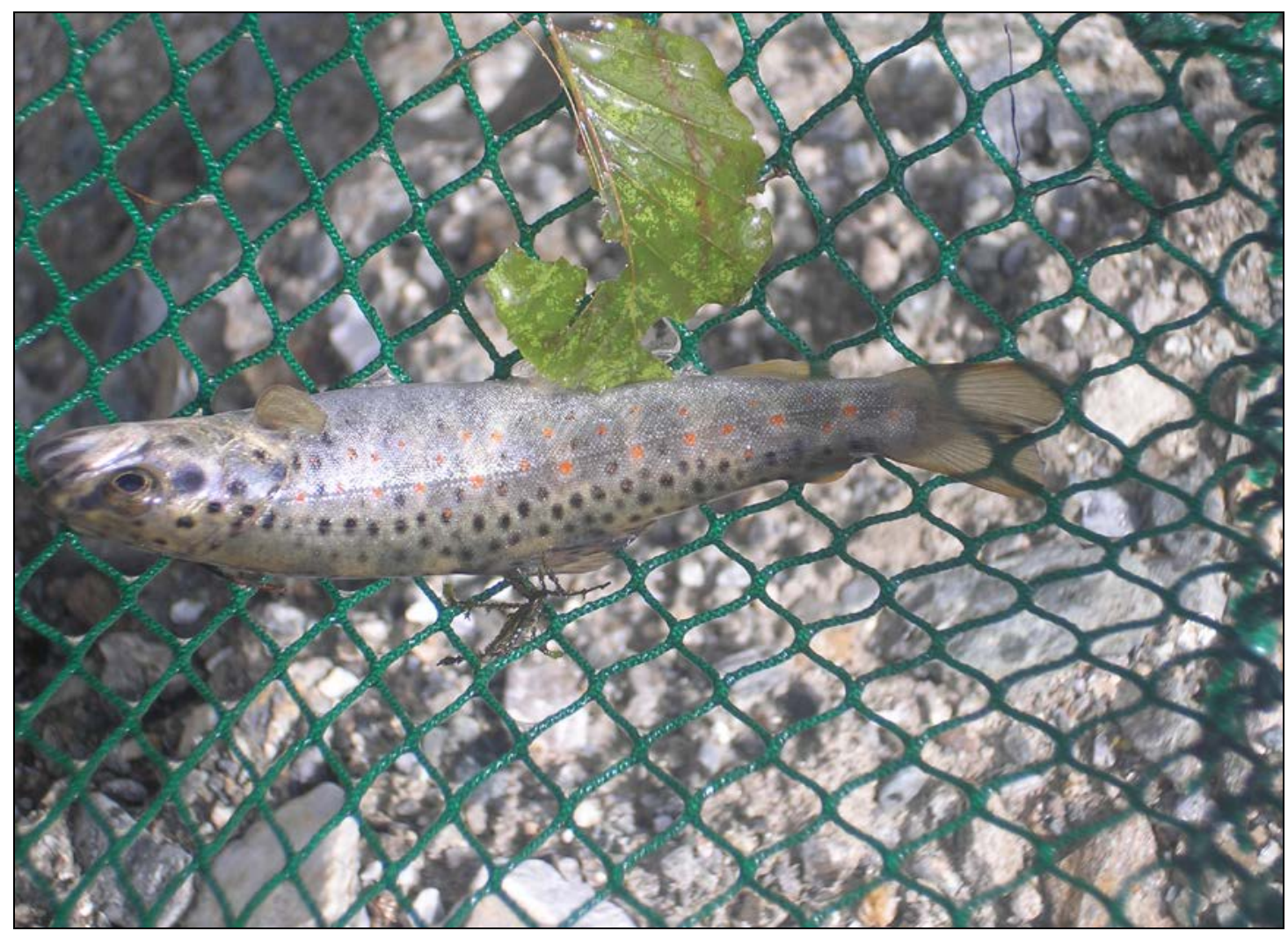

Figure 2: A Salmo trutta fario individual captured during sampling and immediately released after identification.

A significant structural modification appeared in sector B6, upstream of the BerzascaDanube confluence, between collection of the historic data (Bănărescu, 1964) and the new data presented here. The sector is an area where the lotic habitat is modified to a semi-lenitic habitat and impacted by local organic pollution from the nearby Berzasca Village. In the lower sector of the river, many species improved their presence in time and space in comparison with the older data: Gobio gobio obtusirostris had a stronger population than in the past. Sabanejewia aurata bulgarica, Lota lota, Gobio alpininnatus, Aspius aspius, Rutilus rutilus carpathorosicus, Alburnus alburnus, Barbus barbus, Blicca bjoerkna, Abramis brama, Cyprinus carpio, Esox lucius, Perca fluviatilis, Silurus glanis, Scardinius erithrophthalmus, Cobitis taenia, Lepomis gibosus, Acerina cernua, Rhodeus sericeus amarus, Carasius gibelio, Tinca tinca, Misgurnus fosilis, Gobius fluviatilis, Gobius kessleri were all found occasionally in the lower B6 sector. 


\section{Sirinia River}

Sirinia is a small mountainous river with a watershed area category between 100 and $200 \mathrm{~km}^{2}$, a length of between 20 and $50 \mathrm{~km}$ and a mean discharge between 0.2 and $5 \mathrm{~m}^{3} / \mathrm{s}$ (Tetelea, 2014).

As in the Berzasca River, Salmo trutta fario is present in the studied lotic sector, again apparently introduced by humans in the past (Pașovschi, 1956). There was no presence in the ichthyologic trout zone of Cottus gobio and Phoxinus phoxinus. In one part of the Meridional barbell and Grayling zone, Barbus meridionalis remains one of the most abundant fish species of the studied river, although Thymallus thymallus is missing. Orthrias barbatulus have a relatively low abundance. Alburnoides bipunctatus appear to have a good and stable population along the time in this river. Sabanejewia aurata balcanica, Sabanejewia aurata bulgarica, Squalius cephalus and Gobio albipinatus are present in the S4 lower sector, with particularly high populations in summer. Occasional individuals of Gobio gobio obtusirostris, Rhodeus sericeus amarus, Alburnus alburnus, Carasius gibelio, and Perca fluviatilis can be found in the same lower sector.

\section{Mraconia River}

Mraconia is a small mountainous river with a watershed area category between 100 and $200 \mathrm{~km}^{2}$, a length of between 20 and $50 \mathrm{~km}$ and a mean discharge between 0.2 and $5 \mathrm{~m}^{3} / \mathrm{s}$ (Tetelea, 2014).

As in the Berzasca and Sirinia Rivers, Salmo trutta fario is present in the studied lotic sector, again apparently introduced by humans in the past (Pașovschi, 1956). There was no presence in the ichthyologic trout zone for: Cottus gobio and Phoxinus phoxinus. In the Meridional barbell and Grayling zone, Barbus meridionalis remains one of the most abundant fish species, although Thymallus thymallus is missing. Orthrias barbatulus has a relatively low abundance. Alburnoides bipunctatus has a good and stable population here. Sabanejewia aurata balcanica, Sabanejewia aurata bulgarica, Squalius cephalus and Gobio albipinatus in the summer period are present in the S4 lower sector. Occasional individuals in the same lower sector can be found from the following species: Gobio gobio obtusirostris, Rhodeus sericeus amarus, Alburnus alburnus, Carasius gibelio and Perca fluviatilis.

\section{Liubcova/Oreviţa River}

Liubcova/Oreviţa River is a small mountainous river with a watershed area category between 100 and $200 \mathrm{~km}^{2}$, a length of between 20 and $50 \mathrm{~km}$ and a mean discharge between 0.2 and $5 \mathrm{~m}^{3} / \mathrm{s}$ (Tetelea, 2014).

It was not previously studied by Bănărescu (1964). The following fish species were identified in the present study: Barbus meridionalis, Orthrias barbatulus, Alburnoides bipunctatus, Sabanejewia aurata balcanica, and Squalius cephalus. In the summer period Gobio gobio obtusirostris, Rhodeus sericeus amarus, Alburnus alburnus, Carasius gibelio and Perca fluviatilis are present in the L5 lower sector.

\section{CONCLUSIONS}

The relative larger size of the Berzasca River and constant environmental conditions, with relatively stenotopic ichthyocenosis, suffered small qualitative and qualitative changes in time, compared to the smaller rivers such as Sirinia, Liubcova/Oreviţa and Mraconia. Our findings indicate that the effects of anthropogenic impacts and natural topography cause variations in the ichthyofauna of the studied rivers. The Berzasca River, experienced less change, a relatively stenotopic ichthyocenosis and smaller qualitative and quantitative changes over time when compared to the smaller rivers of Sirinia, Liubcova/Oreviţa and Mraconia. 
The discharge regime is a condition for the presence of migratory and semi-migratory fish species upstream or downstream into the studied lotic sectors, and it is contributing to the decrease or increase of fish diversity and changes in fish population size. The accidental droughts in the karstic sectors of the studied lotic sectors have a negative influence on the local fish fauna continuity, and it seems likely that climate change will increase these influences in the future.

The relative small dimensions of Sirinia, Liubcova/Oreviţa and Mraconia rivers can make them sensitive to future human impact.

All these rivers play an important role for the near Danube "Iron Gates" I Lake lotic fish species of small-medium size, as reproduction and shelter habitats.

A permanent seasonal fish fauna monitoring system is needed for all the northern Danube River tributaries in the Danube "Iron Gates” I Lake area.

\section{ACKNOWLEDGMENTS}

A part of this research was accomplished in the frame of the project "South-western Carpathian Wilderness and Sustainable Development Initiatives", co-financed by a Swiss grant through the contribution to the enlarged European Union. Special gratitude is addressed to the WWF Reșița members for all their friendly support in the field (in alphabetical order): Adăscăliței O., Berchi M., Crîsta R., Grancea A., Gavrilă C., and Sîrbu M. We also thank our students Mesia A. M. and Hodorog V. I. for support during the fieldwork.

1. Antipa G., 1909 - Fauna ihtiologică a României, Publicațiile Fondului Adamachi, 294.

2. Antipa G., 1941 - Marea Neagră, I, Oceanografia, Bioeconomia și Biologia generală a Mării Negre, 30, Academia Română publicațiunile Fondului Adamachi, X, LV. (in Romanian)

3. Bănărescu, P., 1964 - Fauna Republicii Populare Române, Pisces-Osteichthyes, XIII, Edit. Academiei R. P. Române, București, 962.

4. Bănăduc D., Bănăduc A., Lenhardt M. and Guti G., 2014 - "Porțile de Fier/Iron Gates" area (Danube) fish fauna, Transylvanian Review of Systematical and Ecological Research, 16, (in printing).

5. Buşniță T., Brezeanu T., Oltean M., Popescu-Marinescu V., Prunescu-Arion E., Bănărescu P. M., Bogatu D., Gheracopol O., Péterfi L. Ș. and Vasiliu G. A., 1970 - Monografia zonei Porților de Fier, Studiul hidrobiologic al Dunării și al afluenților săi, Edit. Academiei R. S. România, 266. (in Romanian)

6. Curtean-Bănăduc A., 2014 - "Iron Gates” Gorges (Danube River), northern tributaries benthic macroinvertebrate communities, Transylvanian Review of Systematical and Ecological Research, 16, (in printing).

7. Pașovschi S., 1956 - Câteva considerațiuni biogeografice asupra munților Banatului, Ocrotirea naturii, 2. (in Romanian)

8. Tetelea C., 2014 - Morphometric analysis to extrapolate geological potential of the rivers in the "Iron Gates" Natural Park (Banat, Romania), Transylvanian Review of Systematical and Ecological Research, 16, (in printing), 29-46.

9. Ujvari I., 1972 - Hidrografia Republicii Populare Române, Edit. Științifică, București, 577. (in Romanian) 